\title{
Tampering with Qur'anic True Meanings of Miracles
}

\author{
Mohammad Ahmad Alkuran ${ }^{1}$ \\ ${ }^{1}$ Translation Department, Yarmouk University, Irbid, Jordan \\ Correspondence: Mohammad Ahmad Alkuran, Translation Department, Yarmouk University, Irbid, Jordan. \\ E-mail: mkuran9@gmail.com
}

$\begin{array}{lr}\text { Received: April 24, } 2013 & \text { Accepted: May 23, } 2013 \quad \text { Online Published: June 28, } 2013 \\ \text { doi:10.5539/ass.v9n9p179 } & \text { URL: http://dx.doi.org/10.5539/ass.v9n9p179 }\end{array}$

\begin{abstract}
Lack of reference in the Holy Qur'an to the verses that Allah intended to be taken either literally or allegorically has left the door open for some sectarian interpreters to deliberately ignore the Qur'anic literal meaning and opt only for the allegorical meanings, with a view of distorting the underlying significance of this great book. This paper does not intend to show that the literal meaning is invariably given pre-eminence over the allegorical meaning. Rather, it intends to demonstrate that some interpreters are prone only to allegorical interpretation just to skew the true message of the Qur'an and minimize its worth. The paper will expose the misinterpretations of Ahmad Ali and his fellows concerning miracles of Ibrahim, Moses, David, and Solomon as a representative sample of the study. Then it ends by refuting the metaphorical approach of interpretation, especially when the miracles are in question.
\end{abstract}

Keywords: blasphemy, allegorical, tamper, cosmological, miracles

\section{Introduction}

While dispute over whether Allah intended His word to be interpreted literally or allegorically is plausibly justifiable when it comes to interpreting His attributes, there is no point of taking His miracles in their allegorical sense, since the Holy Qur'an speaks of the miracles as authentic incidents to prove the omnipresence of the Al mighty. Yet, there are some sectarian interpreters, chiefly Qadians, who take the advantage of the allegorical approach of interpretation just to tamper with the authentic meanings of this great book, especially in the realm of miracles and supernatural incidents to promote the false interpretation of it and prove that it is in harmony with the well-known concepts of science. Since tapping upon all miracles falls beyond the scope of the study, this paper will focus on a limited number of examples to highlight Qadiani distortions against the Qur'an. This will be followed by a refutation of the metaphorical approach of interpretation since miracles are provided as concrete evidence to support the persons upon whom God bestowed His revelations.

\section{Background of the Study}

The Qadians consider the founder of their sect the Mirza Gulaam, the Grand reformer and even the promised Messiah. This claim seems to derive from their denial of the finality of prophet-hood. According to Ansāri (1990: 30), the Mirza makes of himself champion of Islam by introducing such a strange theme that the "Divine inspiration has not ceased to exist and should not cease". This view intends to prove that external and internal knowledge originally bestowed upon prophets could pass on to their followers. This intuitive knowledge is not exclusively limited to the companions of the prophet, but may involve any person who has faith in the prophet.

The underlying motive behind such claim is to prove that the early Muslim scholars have no advantage over any other follower in the interpretation of the Qur'an. In other words, the authority of the interpretation, according to Qadians, should not be only seen as vested in the companions of the Prophet, and consequently opinions may come into play in the construal of the verses. According to Ansāri, the Mirza "gave full rein of his fancy to explain Prophetic traditions in such a way that it is even inconceivable that people should take such liberty in explaining the writing or even compositions of writers or poets. To this end, the Mirza claims that the words of traditions are of figurative or metaphorical nature." (p.49). Such distortion against the ordinary fashion of interpretation is intended to show that "this Great Book has been a mystery or puzzle for over 13 centuries" (Annadawi, 1982:154)

The metaphorical interpretation of the miracles appears to be identical with the disbelief in the unseen world. It follows that cosmological and personal miracles are unwelcome by major Qadiani interpreters such as 
Mohammad Ali and Ahmad Ali, who did a lot of hair-splitting to skew the true meanings of the Holy Qur'an. Their ultimate goal is to minimize the underlying significance of this scripture and present it before the modern world tradition as an ordinary book that speaks of normal human experiences.

This paper thus will expose their twisted interpretations of the Qur'anic miracles by gauging a reasonable number of miraculous incidents against the Qadiani interpretations and commentaries. The paper ends by refuting the metaphorical approach of interpretation as far as miracles are concerned.

As for the transcription system, the Romanization system is used in the reproduction of the Arabic sounds according to the orthographic rules of Arabic.

\section{Discussion}

\subsection{Denial of Ibrahim's Miracle}

Qadians essentially reject Qur'anic miracles bestowed by God upon His chosen prophets. Apparently, they do not believe in the extraordinary incidents that prophets performed to convince their folks of their true callings. The miraculous incidents have been interpreted in a metaphorical fashion by well known Qadiani interpreters like Maulana Mohammad Ali and Ahmad Ali whose commentaries are lengthy and running counter to the known usages of terms by native Arabic speakers and principles of Qur'anic interpretation known to the early Qur'anic interpreters.

Such religious inclination of interpretation is geared toward proving that prophets are nothing more than normal people whose actions are natural. True though this may be, Qadians play blind to the fact that miracles bestowed upon people by the will of God are not subject to the laws of nature. Rather, they are beyond the rules of nature and their goal is to impoverish people and show their inferiority to God. Some miracles are clearly delineated in the Qur'an as concrete evidence of prophets' declarations and are therefore designated to be understood so. Nevertheless, some Qadiani interpreters tend to disregard the literal sense of these miracles to make them natural and perceptible.

In the case of Ibrahim, God commanded fire to be coolness and peace for Ibrahim after having been cast into it. After Ibrahim had smashed his folk's idols, they had a grudge against him and plotted to either kill him or burn him, but God brought him out of the fire unharmed:

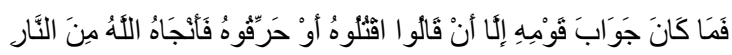

famā kāna jawābu Qawmihi illā 'an qālu qtulūhu 'aw arriqūhu fa'anjahu llāhu mina nnār [Qur'an 29:24], which Ali translates as follows "but the answer of his folk was only that they said: "kill him", or "burn him", then Allah saved him from the fire" [Qur'an 29 :82]. The way God saved Ibrahim from the fire was by commanding it to be cool and peaceful for him such that Ibrahim was unharmed:

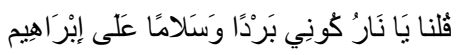

qulna yā nāru kūni bardan wasalāman lā ibrāhim. Though Mohammad Ali translates it thus: We said: O fire, be coolness and peace for Abraham", he seems to be casting doubts in his commentary on this verse over whether Ibrahim was actually cast into the fire, claiming that no mention of this was made in the Qur'an. Then he wonders whether God saved Ibrahim before or after being thrown into the fire. Then he decides that God saved Ibrahim before he was thrown into the fire by means of a journey to another land just as He saved Mohammad by means of a journey to Madina "It was a flight to another place like the prophet's flight to Madina" (commentary 69 a). Although he claims Ibrahim's history refers deeply to the history of Prophet Mohammad himself, there is no clear evidence that their folks had similar plots against them. The Holy Qur'an clearly states that God had delivered Ibrahim unharmed from the fire and his journey to another place came later. Almost all prophets had journeyed when they felt their lives were in danger, but this does not mean that their migration was executed by a miracle.

Ali's claim that God delivered Ibrahim from the fire by a means of a journey is Ali's forced interpretation of"

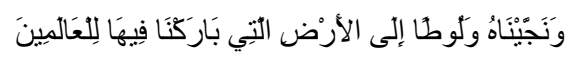

wana ināhu walūtan ilal 'rdi llati bāraknā fihā lilālamin (anbia 71), which he translates as follows: We delivered him and Lot to the land which we had blessed for the nations". He arbitrarily takes this verse as evidence that God saved Ibrahim from the fire by means of a journey to deny the miraculous event of the fire.

\subsection{Fabrications of Moses' Miraculous Incident}

Such disbelief in the supra-natural matters applies to other Qur'anic stories. Ali, for example, denies that Moses split the sea with his staff by the will of God [Qur'an 2: 82]. He even disregards the ordinary senses of the words 
" $s \bar{a}$ ", literally staff "idrib", strike and " $a$ ar", rock and interprets them metaphorically as "a group of people", march or go about, and a mountain" respectively", to prove that there is nothing miraculous about the incident. Let us consider the following verse:

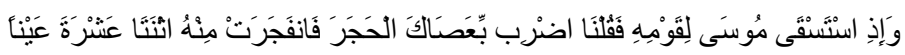

wai istasqa mūsa liqawmihi faqulna idrib $b$ sāka l a arfanfa aratminhu $i$ natā šrata ainan

"And when Moses prayed for water for his people, We said: strike the rock with your staff. So there flowed from it twelve springs [Qur'an 2:60]

In his commentary (96) on the verse, Ali (1984) explains that daraba, to strike' means either strike the rock with your staff or march on or hasten with your folk to a mountain from which water flowed. Ali seems unsure in his commentary of whether Moses actually had struck the rock with a staff or marched with his people to a rock or mountain, though he argues lengthily to prove the metaphorical signification of the incident. His argument, however, is ill founded. He seems to assume that $i d r i b+$ an object always signifies" seeking a way or marching on" as in daraba alard or daraba fil ardi," he travelled. Whereas the foregoing combination gives the sense of " marching on" or "going about", it is quite absurd to take idrib bi'sāka al a ar, literally strike the rock, to mean "march on to the rock". Such analogy is arbitrary and forced"

Likewise, he takes $s \bar{a}$, literally staff, to mean a community or a group of people. The metaphorical sense clearly derives from the hint made of awāri , a deviant Muslim sect, of whom it is said: $\check{s} u q q \bar{u} s \bar{a} l$ muslimina, literally they broke the staff of the Muslims, which he interpreted they made "a schism in the unity or community of the Muslims". Given that the incident that Moses had experienced was supernatural, it ought to be understood as something that" runs counter to our understanding of physical and geological laws". (Ansā ri, 1990: 122). Thus it is absurd to transfer the metaphorical connotation of staff in one context to another context where the word has an ordinary rather than metaphorical sense.

Elsewhere Ali even ignores the means by which Moses saved his folk from the Pharaoh and his men in an attempt to twist the revelation and bring it in line with the spirit of science that ignores the way the unseen world works. In his commentary (82), Ali (1984) claims that the Qur'an "does not show how the Israelities were made to pass through the sea or in what manner the parting of the sea was brought about", though God revealed to Moses to strike the sea with his staff:

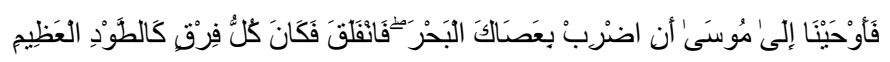

Fa'awhaina ila mūsa 'n idrib bi sāka lbahr fanfalaqa fakāna kullu firqin kattawdil dim, Ali translates this verses as follows: God revealed to Moses to strike the sea with his staff, so it parted, and each part was like a huge mountain [Qur'an šua'rā': 63]. Despite this clear revelation to Moses, Ali plays blind to the bright fact of this supernatural incident. He claims in his commentary that the wind caused the sea to go back by a strong east wind, thus enabling the Israelities to pass through. When Pharaoh and his men came to pass through, the receded water came back and drowned them. Obviously, there is no mention in his commentary that Moses parted the sea by means of his staff as indicated in the verse. His commentary shows no consistency in the way he interprets the same verse that recurs in different places. While he interprets idrib bi sāka al a ar as "march on with your community to a mountain" in Sürat 'lbaqara, verse 60, he comes out saying something completely different in interpreting idrib bi'sāka albahr in Sürat a šurā. The reason might be that he finds it quite hard for any average person to visualize that the sea should part when someone marches on to it with his community, making it possible for them to pass through.

For this reason, Ali came up with the story of the east wind since it is easy to believe and conforms to the laws of nature. He seems to be interpreting the incident in light of his preconceived ideology and expectations that prophets are average people and thus unable to work miracles, simply because there is no reason for miracles to occur in violation of the laws of physics and geology.

Since the concern of the Qadians is to present the Qura'n as palatable and consistent with the laws of science to the detriment of the facts pertaining to the miraculous incidents, they have brought far-fetched interpretations to adjust the Qur'anic significations in line with the geological and physical laws. In his commentary (101) on this verse, for example, Malik Gulām Farid (1969:35) argues that God revealed to Moses "to strike a particular spot where water was just close enough that a strike with a rod would help the water gush out. He considers this within the experience of geologists only to prove that Moses did nothing against the known laws of nature"

The use of $s \bar{a}$ to stand for a group of people is extremely odd. He explains the connection between the "rod" and "people" in terms of the dream language. He attaches importance to dreams and inspiration 


\subsection{Fancy Interpretations Pertinent to David and Solomon}

Such tampering with the authentic meanings is also evident in the text speaking of David and Solomon. Let us consider the following verse:

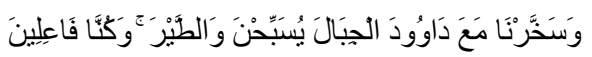

Wasa arnā ma a dāwūda $l$ ibāl yusabbi na wattair wakunna fā'ilin. Mohammad Ali translates this as follows: And made the mountains declaring (our) glory, and the birds, subservient to David. And we were the doers.

His commentary regarding this verse runs contrary to the obvious meaning. He claims that what was subservient to David were not mountains and birds, but mountain dwellers. In other words, to him birds and mountains stand for good people who glorified God with David. There is even no indication in his commentary that mountains and birds do glorify God on their own.

If we were to interpret this verse like Ali's, there would be nothing miraculous about the mountain dwellers glorifying God nor mountains or birds praising God. Actually the Qur'an clearly makes it clear that everything glorifies God [isrā :44], but we, as humans, do not comprehend their praises. The fact that mountains and birds would glorify God with David represents God's grace over David. Thus, the miracle is not that birds and mountains sing praises of God; that is an everlasting fact since the beginning of the creation. Rather, it is that they performed their glorifications of God in the company of David, and no other prophet had ever been endowed with such grace.

Though "tair" in that miraculous incident must be comprehended literally, it has been subject to the adventures of Qadiani interpreters in the realm of the Qur'anic exegeses.

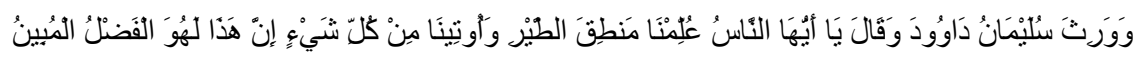

"wa wari a sulaiman dāwūd wa qala ya 'yyuha nnās ullimnā mantiqa attairi wa'ūtina min kulli shai innā ha a lahu al fa lu lmubin. Mohammad Ali translates it thus: "And Solomon was David's heir, and he said: O men, we have been taught the speech of bird, and we have been granted of all things, surely this is manifest grace". [Qur'an 27:16]. In his commentary on the foregoing verse, Mohammad Ali notes that, although tair is commonly used for birds, it can also apply to a winged being and sharp , spirited, vigorous horse that is almost made to fly by reason of the vehemence of its running. It can also stand for a company of men".

Far more striking than that is his endeavor to prove that people signify the jinn:

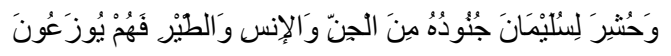

wa hušera lisulaimana junūduhu minal inn wal 'ins wa ttair fahum yūza'ūn. Mohammad Ali translates it thus: his armies of inn and men and tair were brought together before Solomon, formed into ranks. In his commentary, he notes " inn stands for certain types of men belonging to certain mountain tribes whom Solomon had subjugated". The use of tair, "birds" to stand for people is based on feeble evidence. Commenting on this verse, Ahmad Ali (1984: 322) remarks that tair stands for people because mantiq, literally speech," commonly stands for human speech since a human being is known as a speaking animal, whereas the language of birds being called sawt". In response to this claim, one would say that sawt is a common Arabic word that can be collocated with animate and inanimate nouns. It is quite appropriate to say sawt arrih, sound of the wind, sawt arra'd, sound of the thunder, sawt al qit, voice of the cat. This shows that his argument that sawt is only attributed to birds is baseless

Whereas Mohammad Ali takes mantiq metaphorically as the use of birds in conveying messages from one place to another, one may say that the use of birds in conveying messages has not been limited to believers, but included disbelievers as well. Thus if birds are used for such mission by any average person, believer or disbeliever, there would be no reason to call such practice "manifest grace" bestowed by God upon Solomon and his father, because other people could then teach birds to convey messages from one place to another.

This line of arbitrary interpretation also applies to the names of birds. When Solomon checked the birds to see if all the birds had been present, he found that Hudhud "hoopoe" was missing.

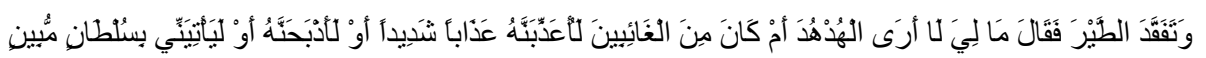

Wa ttafaggada ttaira faqala māli la 'ral hudhud 'm kāna minal gāibin la i ibannahu aban šadidan aw la', bahannahu aw ya'tianni bisultānin mubin. Mohammad Ali translates it thus:

"And he reviewed the birds, then Said: How is it I see not Hudhud, or is it that he is one of the absent [Qur'an 27:

20-21], I will certainly punish him a severe punishment, or he shall bring me a clear excuse". In his commentary, 
however, he falsely encapsulates their names allegorical and symbolic to persuade the reader that Solomon was communicating with human beings, not birds. He claims that "in every language many proper names given to men will be found to be identical with the names of animals" (Commentary 20a). To him, the Arabs spoke of the king of Himyar as hudhud, whereas hudhad was the name of Balqis's father, the queen of Yemen. His point of attributing the names of birds to humans is to prove that Solomon actually inspected humans, not birds. Thus, Solomon was speaking of one of his officers when he inquired about hudhud. To promote his argument further, he finds it curious that such a might monarch, Solomon, should inflict upon a bird as small as a hoopoe a severe punishment and hold it accountable for being absent.

Likewise, Mohammad Ali let his imagination go loose regarding the following verse:

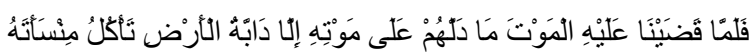

"But when we decreed death upon him, naught showed them (the inn) his death except a creature of the earth that ate his staff [Qur'an 46:14). This verse indicates that when Solomon died, none of the inn sensed his death except until the staff, which had supported his corpse, fell down after a moth had eaten it a way. Although there is no controversy over this explanation by Qur'anic exegetes, Mohammad Ali twists the text by attaching metaphorical significances to it. He claims that the creature of the earth that ate a way Solomon's staff signifies the weak rule of his son who led a luxurious life and gave a free reign to his desires. As for the inn, he claims that they refer to the rebellious tribes that Solomon had subjugated to his rule and remained so until the collapse of his kingdom.

\subsection{Tampering with Cosmological Miracles}

Such type of reasoning is also obvious in the interpretation of cosmological miracles. No less strange than the loose interpretations of the miracles performed by the will of God at the hands of prophets is the explanation of the cosmological events. Just as Mohammad Ali applies his mental framework to the detriment of the obvious meaning of Qur'anic verses, Ahmad Ali extends this line of reasoning to include cosmological events such as the splitting of the moon. God says that the moon was rent asunder:

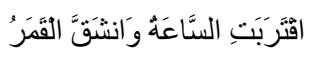

iqtarabati ssā atu wa nšaqqa l qamar, which Ahmad Ali translates thus:

The Hour has drawn nigh, and the moon is rent asunder [Qur'an 54:1]

In his commentary on this verse, however, he denies the actual occurrence of this event and takes it symbolically to mean the advent of Islam that caused the tribe of Quraish to break up, thus neglecting the interpretations of the incident rendered by the Companions of the Prophet as a real one. He says that the Quraish was the dominant Arab tribe all over Arabia. Its emblem was the moon. With the advent of Islam, there was a split in the ranks of the tribe, some accepting Islam, others opposing it. Obviously, he takes the split in the moon as a split in the ranks of this tribe. The basis on which he establishes such kind of metaphor is God's exhortation of the Quraish to be united in the worship of Him, which occurs in another chapter:

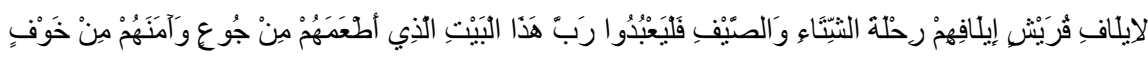

Ahmad Ali translates it thus: Since the Quraish has been united. United to fit out caravans winter and summer. Let them worship the Lord of this house. Who provided them against destitution and gave them security against fear [Qur'an 105: 1-4]

Such level of reasoning is arbitrary. This chapter by no means suggests God's response to the fabricated story that the split was not in the moon, but in the ranks of the Quraish. It is ironic to believe that because of the split God exhorted the Quraish to be united in the worship of Him. What Ahmad Ali has effected is indeed distortions against the true meaning of the Holy Qur'an.

In a similar vein, Farid (1969) goes loose in his interpretation of this incident when he takes the Hour as the hour of destruction of the power of Quraish in the Battle of Badr, the first military confrontation between Mohammad and his enemies from Quraish. Thus according to him, the verse would mean that the hour of the overflow of Quraish has come and the rise of the Prophet as the true Divine Messenger is imminent. This interpretation is taken in terms of the dream language, where the moon fall or split suggests death of a person or end of a rule.

Such feeble interpretations are similar to the arbitrary reasoning of Mirza Gul ām, founder of Qadinism, who claims that the Christ died in Kashmir which was originally Kashir. According to him, Kashir is composed of the letter $\mathrm{K}$ which is used to signify resemblance and "ashir" which denotes Palestine in Hebrew. "When Jesus migrated from Palestine to Kashmir because of the pleasant weather, greenery and freshness, God Called it Kashir, but the excessive use of the word led to the dropping of one "a" with the result that it became Kashir" 
(Ansaari 1990: 122)

\section{Refutations of Qadiani Interpretations}

There seems to be no doubt that the Qadiani interpretations of the miraculous events seem to have based on preconceived ideas while disregarding the true meanings agreed upon by major Muslim exponents and exegetes. Obviously, they interpret miraculous incidents metaphorically because they do not believe in supernatural matters, which in turn distort the underlying significance of these miracles. Such approach gives a free reign to their fancy interpretations contrary to the interpretations of the great Muslim scholars and companions of the Prophet, who rendered miracles in their ordinary senses since a miracle is a proof that the Prophet is being supported by the Divine revelation. When one lets his imagination go, the interpretation becomes a plaything that anyone may claim the right to derive from the Holy Qur'an whatever pleases him of meanings.

To attach importance to the metaphorical interpretation of the miracles is to open the door wide for all sorts of explanations that suit the preconceived ideas and ideology of the interpreters. If the meaning is believed to be in the head of the reader, as the Qadians may seem to suggest, then the author of the text is dead. While this notion is a principle promoted by post-structuralists, who assert that meaning is multiple and subject to all kinds of experiences and understandings, the Holy Qur'an and all other revelations should not be subject to such manipulation.

A miracle is a practical rather than metaphorical response of the Prophets to a strong demand by people for a clear proof. To be convincing that it is from God, it must be concrete and beyond man's capacity. The splitting of the sea, the glorification of birds and mountains with David, and the bringing of water out of a rock by virtue of a strike are all miraculous incidents that must be understood literally as concrete evidence that the prophet upon whom the miracle is bestowed is chosen and supported by God.

It is dishonest therefore to subject the miraculous events to the physical laws of nature. Miracles were never intended to be performed by any person other than those upon whom God had bestowed His grace, and the will of God is never questionable. Miracles are not for people to learn from how geological and physical laws work, neither are they performed to be a puzzle or mystery.

The interpreters' fault lies in the fact that by forcing the meanings of the Qur'an to the spirit of science, they are giving science the authority over the word of God, which is an indication that they may have no faith in the Holy Qur'an or Islamic tradition in the first place.

\section{References}

Ali, A. (1984). Al Qur'an, A contemporary Translation. Karachi: Akrash Publishing.

Ali, M. (2002). The Holy Qur'an: Arabic Text with English Translation, Commentary and Comprehensive Introduction. Lahore: Anjuman Isha'at

Ansāri, Z. (1990). Qadianism. A Critical Study. Islam Abād: International lamic University.

Annadawi, A. A. (1982). The Qadian and Qdianism, An Aalytical Sudy. Madinah Munawwarah: The slamic University Press.

Farid, M. (1969). The Holy Qur'an: English Translation with Short Commentary. Lahore: Islam International.

\section{Copyrights}

Copyright for this article is retained by the author(s), with first publication rights granted to the journal.

This is an open-access article distributed under the terms and conditions of the Creative Commons Attribution license (http://creativecommons.org/licenses/by/3.0/). 